OPEN ACCESS

Edited by: Norbert Müller,

Ludwig Maximilian University of Munich, Germany

Reviewed by: Margaret K. Hahn

University of Toronto, Canada

Francesca Managò, Italian Institute of Technology (IIT), Italy

*Correspondence: David R. Goldsmith drgolds@emory.edu

Specialty section: This article was submitted to

Schizophrenia,

a section of the journal

Frontiers in Psychiatry

Received: 28 October 2019 Accepted: 20 January 2020

Published: 20 February 2020

Citation:

Goldsmith DR and Rapaport MH (2020) Inflammation and Negative

Symptoms of Schizophrenia: Implications for Reward Processing and Motivational Deficits.

Front. Psychiatry 11:46. doi: 10.3389/fpsyt.2020.00046

\section{Inflammation and Negative Symptoms of Schizophrenia: Implications for Reward Processing and Motivational Deficits}

\author{
David R. Goldsmith ${ }^{*}$ and Mark Hyman Rapaport
}

Department of Psychiatry and Behavioral Sciences, Emory University School of Medicine, Atlanta, GA, United States

Negative symptoms of schizophrenia are debilitating and chronic in nature, are difficult to treat, and contribute to poor functional outcomes. Motivational deficits are a core negative symptom and may involve alterations in reward processing, which involve subcortical regions such as the basal ganglia. More specifically, dopamine-rich regions like the ventral striatum, have been implicated in these reward-processing deficits. Inflammation is one mechanism that may underlie negative symptoms, and specifically motivational deficits, via the effects of inflammatory cytokines on the basal ganglia. Previous work has demonstrated that inflammatory stimuli decrease neural activity in the ventral striatum and decrease connectivity in reward-relevant neural circuitry. The immune system has been shown to be involved in the pathophysiology of schizophrenia, and inflammatory cytokines have been shown to be altered in patients with the disorder. This paper reviews the literature on associations between inflammatory markers and negative symptoms of schizophrenia as well as the role of anti-inflammatory drugs to target negative symptoms. We also review the literature on the role of inflammation and reward processing deficits in both healthy controls and individuals with depression. We use the literature on inflammation and depression as a basis for a model that explores potential mechanisms responsible for inflammation modulating certain aspects of negative symptoms in patients with schizophrenia. This approach may offer novel targets to treat these symptoms of the disorder that are significant barriers to functional recovery and do not respond well to available antipsychotic medications.

Keywords: inflammation, cytokines, negative symptoms, reward, motivation, schizophrenia

\section{NEGATIVE SYMPTOMS: A FOCUS ON MOTIVATIONAL DEFICITS AND REWARD PROCESSING}

Schizophrenia is a severe mental illness that affects $1 \%$ of the population and accounts for over $\$ 60$ billion in US healthcare costs $(1,2)$. Up to $30 \%$ of individuals with schizophrenia are considered "treatment-resistant," adding to even greater morbidity and socioeconomic burden $(3,4)$. The disorder is a major public health concern, and many people with schizophrenia suffer chronic 
debilitating symptoms $(5,6)$, have high rates of unemployment and homelessness in the US $(7,8)$, and have a significantly reduced life expectancy (9).

In contrast to delusions and hallucinations that constitute the positive symptoms of schizophrenia, negative symptoms characterize absent or diminished behavior and include motivational deficits, social withdrawal, poverty of speech, decreased emotional reactivity and psychomotor expression, and deficits in volition $(10,11)$. Negative symptoms are common and are thought to be present in over half of patients, with reports in the literature ranging from 60 to $90 \%(12,13)$. These negative symptoms may be primary in nature (i.e., thought to be driven by underlying pathophysiology of the disorder). Alternatively, they may be secondary to other causes, including positive symptoms (i.e., amotivation to leave the house secondary to paranoid delusions), depression, anxiety, or side effects of medications (i.e., lack of facial affect secondary to extrapyramidal symptoms) (14). The literature has also described a subtype of schizophrenia referred to as "deficit schizophrenia," which is marked by primary and enduring negative symptoms, and is thought to occur in $\sim 20 \%$ of individuals with schizophrenia (15). Negative symptoms are common in individuals with treatment resistant schizophrenia, and may explain the most variance in disease severity and mediate the relationship between disease severity and cognitive deficits in this patient population $(16,17)$. Importantly, negative symptoms are consistently shown to be predictive of functional impairment and poor outcome in patients with schizophrenia, more so than positive symptoms of the disorder (18-22). Current antipsychotics do not adequately treat negative symptoms, which remain a distinct challenge in the treatment and management of patients with schizophrenia $(23,24)$.

Impaired reward processing and motivational deficits are the negative symptoms most predictive of poor quality of life and functional impairment $(11,25-28)$ : patients often fail to expend effort to seek out rewarding activities such as work and social interaction. These motivational deficits can be further delineated into four measurable domains: decreased reward anticipation, impaired reinforcement learning, reward prediction errors, and reduced effort-cost computation (29). It is also important to note that given the current focus of the National Institute of Mental Health to discover mechanisms underlying dimensions of behavior using a transdiagnostic approach (Research Domain Criteria, $\mathrm{RDoC}$ ), decreases in motivation and reward processing seen in negative symptoms of schizophrenia as well as depression fall under the RDoC domain of Positive Valence Systems (30-32).

Subcortical brain regions including the basal ganglia, and specifically the ventral striatum, are part of a distributed brain network that subserves all of these domains, which also include the ventral tegmental area, prefrontal cortex, and anterior cingulate cortex among others $(33,34)$. Neuroimaging studies demonstrate reduced ventral striatal responses to reward anticipation (35-38), reinforcement learning $(39,40)$, and positive prediction errors for patients with schizophrenia (4144). Patients with schizophrenia also have decreased objective reward processing as measured by assessments of effort expenditure for reward and reinforcement learning (45-56), which are known to involve ventral striatal circuits $(35-37,48$, 57-59). Decreased activity in the ventral striatum on a monetary reward based neuroimaging task has been directly related to both objective and clinical assessments of decreased motivation in patients with schizophrenia (48). Decreased ventral striatal activity and task performance have been consistently related to severity of negative symptoms $(39,46,48,51,53,54,56,60)$. Moreover, patients with treatment resistant schizophrenia with significant negative symptom severity, may have different neural reward processing responses relative to those who are treatmentresponsive (61). These converging findings suggest that reward processing deficits are a core component of negative symptoms in schizophrenia.

Heterogeneity in clinical presentation and etiology of schizophrenia presents a challenge to discovering pathways and mechanisms that underlie the complex symptoms of the disorder (62-64). Despite the challenges of disentangling this heterogeneity, understanding mechanisms that may underlie symptoms of the disorder are important to consider and investigate. Inflammation may represent one pathophysiologic mechanism that underlies motivational and reward processing deficits in patients with schizophrenia. Although multiple aspects of the immune system have been implicated in the pathophysiology of schizophrenia, we will focus on the role of inflammation. Our previous meta-analysis (65) demonstrated alterations in peripheral inflammatory markers in patients with not only acute exacerbations of symptoms of schizophrenia, but also in chronically ill patients with schizophrenia where negative symptoms tend to be most prominent. This paper presents the evidence for the role of inflammation in schizophrenia, reviews data showing associations between inflammatory markers and negative symptoms, and presents data from treatment trials with anti-inflammatory medications. This review will also discuss data showing relationships between inflammatory cytokines and motivational deficits in other psychiatric disorders that may provide a framework for studying these relationships in patients with schizophrenia. Finally, we will propose future directions to drive forward research investigating novel mechanisms that may be responsible for negative symptoms and motivational deficits in some patients with schizophrenia.

\section{MULTIPLE LINES OF EVIDENCE IMPLICATE INFLAMMATION AND THE IMMUNE SYSTEM IN THE PATHOGENESIS OF SCHIZOPHRENIA}

Epidemiological studies demonstrated that exposure to infections in utero and in childhood increases the risk for schizophrenia (66-68). Autoimmune conditions are more prevalent in both individuals with schizophrenia and their first-degree relatives $(69,70)$. Moreover, genome-wide 
association studies have repeatedly shown an association between schizophrenia and immune genes, including the major histocompatibility complex region on chromosome 6 (71-73). These findings are consistent with data that the complement pathway (innate immune system) may play a fundamental role in the development and progression of the syndrome via effects on synaptic pruning (74). In a meta-analysis, we reported that patients with schizophrenia reproducibly exhibit alterations in peripheral inflammatory marker concentrations (65), and several of the included studies reported associations between cytokines and negative symptoms (75-80).

\section{INSIGHTS INTO THE EFFECTS OF INFLAMMATION ON NEGATIVE SYMPTOM OF SCHIZOPHRENIA}

A number of groups have reported associations between inflammatory markers and negative symptoms of schizophrenia, although many of these studies have only investigated a single inflammatory marker. Another of the challenges with these studies has been the focus on a variety of different stages of illness. Moreover, the majority of these analyses are correlative in nature. Thus it is challenging to formulate a coherent understanding of the role of inflammation in the pathogenesis of negative symptoms. Table 1 summarizes these findings that report an association between inflammation and negative symptoms.

A few studies have investigated the role of C-reactive protein (CRP), an acute phase protein synthesized by the liver that can be induced by cytokines $(88,89)$, and has been shown to be elevated in patients with schizophrenia in multiple meta-analyses $(90,91)$. Early work (81) demonstrated that inpatients with schizophrenia $(n=5)$ with CRP $>0.5 \mathrm{mg} / \mathrm{dl}$ had higher scores on the Positive and Negative Syndrome Scale (PANSS) negative symptom score than those inpatients with schizophrenia with $\mathrm{CRP}<0.5 \mathrm{mg} / \mathrm{dl}$ $(\mathrm{n}=21)$. The high CRP group had higher scores on all subscales (and total score) of the PANSS, which could reflect the effect of the stress of acute psychosis stimulating an inflammatory response rather than a specific interaction between inflammation and negative symptoms. Boozalis et al. found a modest relationship between CRP and negative symptoms as assessed by the PANSS in a small sample ( $\mathrm{n}=$ 39) of patients with schizophrenia that remained significant after adjusting for age, sex, race, and body mass index (BMI) (82). Similarly, Liemburg et al. found that CRP was correlated to PANSS negative score (as well as positive score) in a large sample $(n=2,132)$ of outpatients with chronic schizophrenia in the Netherlands (83).

Inflammatory markers such as CRP have been elevated in patients with deficit schizophrenia, which is a term used to describe patients who suffer mostly primary and enduring negative symptoms despite attempts to optimize medication interventions $(14,92)$. In a study of deficit compared to non- deficit patients, both CRP and interleukin (IL)-6 concentrations were higher in the deficit group (75). Goldsmith et al. extended this work, finding higher concentrations of the proinflammatory cytokines tumor necrosis factor (TNF) and interleukin (IL)-6 in deficit patients compared to both nondeficit patients and healthy controls (84). Moreover, TNF (but not IL-6) was associated with PANSS negative scores (and not other subscale scores) in linear regression models.

Other studies have examined the relationship between a number of different inflammatory cytokines and negative symptoms across the spectrum of psychosis, from individuals at clinical high risk to first episode to chronic schizophrenia. Stojanovic and colleagues found that increased concentrations of IL- 6 were associated with higher negative symptom scores on the PANSS in both individuals determined to be at an at-risk mental state as well as young individuals diagnosed with a psychotic disorder (77). In a study of clinically high risk individuals from the North American Prodromal Longitudinal Study (NAPLS), higher concentrations of TNF predicted worse negative symptom trajectories at 1 year follow up whereas lower IL-6 concentrations predicted worsening negative symptoms trajectories (85). Although it is unclear why the findings for TNF and IL- 6 diverged, one possible explanation may have to do with the pleiotropic nature of IL- 6 in the immune response $(93,94)$. For example, IL-6 may exert its pro-inflammatory effect via trans-signaling with its soluble receptor, whereas IL6 may also have anti-inflammatory properties via classical signaling pathways involving membrane-bound IL-6 receptors and the signal transducing beta-subunit glycoprotein 130 (gp130) $(95,96)$.

One study has examined the relationship between inflammatory biomarkers and negative symptoms in first episode psychosis. Xiu et al. found that drug naïve first episode patients had decreased concentrations of IL-10, an antiinflammatory cytokine, relative to matched controls, and IL-10 was inversely correlated with negative symptoms severity on the PANSS (78). Interestingly, recent work from Zhu et al. showed elevated TNF-a and IL-1beta in patients with chronic schizophrenia compared to healthy controls, whereas drug naive first episode patients had lower concentrations compared to both the chronic patients and controls (86). Both TNF and IL1beta were correlated with PANSS negative subscale scores in chronic patients, but not in the first-episode cohort.

Other studies of chronic patients with schizophrenia have also shown relationships between cytokines and cytokine receptors and negative symptoms. Asevedo et al. found that individuals with chronic schizophrenia had lower concentrations of IL-2 compared to controls, and IL-2 was negatively correlated with PANSS negative symptoms scores (76), consistent with findings from Bresee and Rapaport who demonstrated that soluble IL-2 receptor (sIL-2r) was correlated with PANSS negative, general, and total scores (87).

All of the above studies (save for the two from Goldsmith et al.) measured single inflammatory markers, which may not provide a full understanding of which inflammatory markers 
TABLE 1 | Description of studies showing associations between inflammatory markers and negative symptoms of schizophrenia.

\begin{tabular}{|c|c|c|c|c|c|c|c|}
\hline & $\begin{array}{l}\text { Markers } \\
\text { studied }\end{array}$ & $\begin{array}{l}\text { Serum/ } \\
\text { plasma }\end{array}$ & Assay & $\begin{array}{l}\text { Population } \\
\text { studied }\end{array}$ & $\mathbf{N}$ & $\begin{array}{l}\text { Factors controlled } \\
\text { for/included in } \\
\text { statistical models }\end{array}$ & Comments \\
\hline Fan et al. (81) & CRP & Serum & $\begin{array}{l}\text { Particle enhanced } \\
\text { immunonephelometry }\end{array}$ & $\begin{array}{l}\text { Inpatients with } \\
\text { schizophrenia/ } \\
\text { schizoaffective } \\
\text { disorder; no control } \\
\text { group }\end{array}$ & 26 & None & $\begin{array}{l}\text { High CRP group (>0.5 mg/dl; } \\
\mathrm{n}=5 \text { ) had higher PANSS scores } \\
\text { on all subscales, including } \\
\text { negative symptoms }\end{array}$ \\
\hline Boozalis et al. (82) & $\mathrm{CRP}$ & Plasma & ELISA & $\begin{array}{l}\text { Inpatients with } \\
\text { schizophrenia; no } \\
\text { control group }\end{array}$ & 39 & Age, sex, race, BMl & $\begin{array}{l}\text { Positive correlation between } \\
\text { CRP and PANSS negative } \\
\text { symptoms both unadjusted and } \\
\text { after adjusting for age, sex, race, } \\
\text { and BMl }\end{array}$ \\
\hline $\begin{array}{l}\text { Liemburg et al. } \\
\text { (83) }\end{array}$ & CRP & $\begin{array}{l}\text { Plasma } \\
\text { and } \\
\text { Serum } \\
\text { collected } \\
\text { from } \\
\text { different } \\
\text { sites }\end{array}$ & $\begin{array}{l}\text { Varied by sites; } \\
\text { specific assays not } \\
\text { disclosed }\end{array}$ & $\begin{array}{l}\text { Outpatients from } \\
\text { four different sites in } \\
\text { the northern } \\
\text { Netherlands; no } \\
\text { control group }\end{array}$ & 2123 & $\begin{array}{l}\text { Age, sex, smoking, } \\
\text { use of anti- } \\
\text { histaminergic } \\
\text { antipsychotics, } \\
\text { statins, fibrates, } \\
\text { corticosteroids, } \\
\text { antibiotics, } \\
\text { chlorpromazine } \\
\text { equivalents, BMl, } \\
\text { metabolic syndrome, } \\
\text { metabolic effects of } \\
\text { antipsychotics (high, } \\
\text { medium, low) }\end{array}$ & $\begin{array}{l}\text { Association between CRP and } \\
\text { PANSS negative symptom } \\
\text { subscale in linear regression } \\
\text { models }\end{array}$ \\
\hline $\begin{array}{l}\text { Garcia-Rizo e al. } \\
(75)\end{array}$ & $\begin{array}{l}\text { CRP and } \\
\text { IL-6 }\end{array}$ & $\begin{array}{l}\text { Not } \\
\text { described }\end{array}$ & $\begin{array}{l}\text { IL-6: ELISA } \\
\text { CRP: not described }\end{array}$ & $\begin{array}{l}\text { Antipsychotic naïve } \\
\text { patients with first } \\
\text { episode } \\
\text { nonaffective } \\
\text { psychosis; no } \\
\text { control group }\end{array}$ & $\begin{array}{l}20 \text { patients with } \\
\text { deficit psychosis } \\
\text { and } 42 \text { patients } \\
\text { with non-deficit } \\
\text { psychosis }\end{array}$ & $\begin{array}{l}\text { Groups matched for } \\
\text { age, sex, BMl, } \\
\text { smoking }\end{array}$ & $\begin{array}{l}\text { Higher concentrations of CRP } \\
\text { and IL-6 in the deficit group } \\
\text { compared to the non-deficit } \\
\text { group }\end{array}$ \\
\hline $\begin{array}{l}\text { Goldsmith et al. } \\
\text { (84) }\end{array}$ & $\begin{array}{l}\text { IFN- } \gamma, \text { IL- } \\
1 \beta, I L-6 \\
\text { sIL-2R, } \\
\text { TNF }\end{array}$ & Plasma & $\begin{array}{l}\text { Multiplex } \\
\text { immunoassay }\end{array}$ & $\begin{array}{l}\text { Outpatients with } \\
\text { schizophrenia and } \\
\text { healthy controls }\end{array}$ & $\begin{array}{l}17 \text { with deficit } \\
\text { schizophrenia, } 39 \\
\text { with non-deficit } \\
\text { schizophrenia, } 28 \\
\text { controls }\end{array}$ & $\begin{array}{l}\text { Smoking, BMI, } \\
\text { education }\end{array}$ & $\begin{array}{l}\text { Higher concentrations of IL-6 } \\
\text { and TNF in deficit patients } \\
\text { compared to non-deficit and } \\
\text { controls. TNF associated with } \\
\text { PANSS negative symptoms in } \\
\text { linear regression models }\end{array}$ \\
\hline $\begin{array}{l}\text { Stojanovic et al. } \\
(77)\end{array}$ & $\begin{array}{l}\text { IL-6, } \\
\text { CRP, } \\
\text { fibrinogen }\end{array}$ & Serum & $\begin{array}{l}\text { CRP by } \\
\text { immunoturbidimetry } \\
\text { assay; IL- } 6 \text { by ELISA }\end{array}$ & $\begin{array}{l}\text { Outpatients with } \\
\text { psychotic disorder } \\
\text { (PD), ARMS } \\
\text { subjects, healthy } \\
\text { controls }\end{array}$ & $\begin{array}{l}77 \text { with psychotic } \\
\text { disorder, } 17 \text { ARMS } \\
\text { subjects, } 25 \\
\text { controls }\end{array}$ & $\begin{array}{l}\text { Sex, BMI, substance } \\
\text { use, antipsychotic } \\
\text { treatment, IL-6 } \\
\text { rs1800795 genotype }\end{array}$ & $\begin{array}{l}\text { Higher concentrations of IL-6 in } \\
\text { ARMS compared to control } \\
\text { group and in PD compared to } \\
\text { control that becomes trend-level } \\
\text { after Bonferroni correction. CRP } \\
\text { differences between groups do } \\
\text { not meet significance after } \\
\text { Bonferroni correction. IL-6 } \\
\text { associated with negative } \\
\text { symptoms in linear regression } \\
\text { models for both PD and ARMS } \\
\text { subjects }\end{array}$ \\
\hline $\begin{array}{l}\text { Goldsmith et al. } \\
\text { (85) }\end{array}$ & $\begin{array}{l}\text { IFN- } \gamma, \text { IL- } \\
1 \beta, \text { IL- } \\
1 R A, \text { IL-4, } \\
\text { IL-6, IL-8, } \\
\text { IL-10, } \\
\text { TNF }\end{array}$ & Plasma & $\begin{array}{l}\text { Multiplex } \\
\text { Immunoassay }\end{array}$ & $\begin{array}{l}\text { CHR subjects; no } \\
\text { control group }\end{array}$ & 37 & $\begin{array}{l}\text { Age, sex, race, } \\
\text { weight, baseline } \\
\text { negative symptoms, } \\
\text { baseline CDSS } \\
\text { scores }\end{array}$ & $\begin{array}{l}\text { Higher concentrations of TNF } \\
\text { and lower concentrations of IL-6 } \\
\text { predicted worse negative } \\
\text { symptom trajectories at one year } \\
\text { follow up }\end{array}$ \\
\hline Xiu et al. (78) & $\mathrm{IL}-10$ & Serum & ELISA & $\begin{array}{l}\text { First episode drug } \\
\text { naïve inpatients } \\
\text { with schizophrenia; } \\
\text { heathy controls }\end{array}$ & $\begin{array}{l}128 \text { patients with } \\
\text { schizophrenia; } 62 \\
\text { controls }\end{array}$ & $\begin{array}{l}\text { Sex, age, education, } \\
\text { smoking, BMl }\end{array}$ & $\begin{array}{l}\text { Decreased IL-10 concentrations } \\
\text { in the patients compared to } \\
\text { controls. IL-10 was inversely } \\
\text { correlated with negative } \\
\text { symptoms severity on the } \\
\text { PANSS. }\end{array}$ \\
\hline Zhu et al. (86) & $\begin{array}{l}\text { TNF and } \\
\| \mathrm{L}-1 \beta\end{array}$ & Serum & ELISA & $\begin{array}{l}\text { First episode drug } \\
\text { naïve patients with }\end{array}$ & $\begin{array}{l}69 \text { first episode } \\
\text { patients, } 87\end{array}$ & $\begin{array}{l}\text { Age, sex, course of } \\
\text { illness }\end{array}$ & $\begin{array}{l}\text { TNF and IL-1 } \beta \text { concentrations } \\
\text { were lower in first episode }\end{array}$ \\
\hline
\end{tabular}


TABLE 1 | Continued

\begin{tabular}{|c|c|c|c|c|c|c|c|}
\hline & $\begin{array}{l}\text { Markers } \\
\text { studied }\end{array}$ & $\begin{array}{l}\text { Serum/ } \\
\text { plasma }\end{array}$ & Assay & $\begin{array}{c}\text { Population } \\
\text { studied }\end{array}$ & $\mathbf{N}$ & $\begin{array}{l}\text { Factors controlled } \\
\text { for/included in } \\
\text { statistical models }\end{array}$ & Comments \\
\hline & & & & $\begin{array}{l}\text { schizophrenia (both } \\
\text { in and outpatients), } \\
\text { chronic patients } \\
\text { with schizophrenia } \\
\text { (both in and } \\
\text { outpatients), and } \\
\text { healthy controls }\end{array}$ & $\begin{array}{l}\text { patients with } \\
\text { chronic } \\
\text { schizophrenia, } 61 \\
\text { healthy controls }\end{array}$ & & $\begin{array}{l}\text { patients compared to healthy } \\
\text { controls and higher in chronic } \\
\text { patients compared to controls. } \\
\text { Concentrations of both were } \\
\text { correlated with the PANSS } \\
\text { negative subscale in chronic, but } \\
\text { not first episode patients. }\end{array}$ \\
\hline $\begin{array}{l}\text { Asevedo et al. } \\
(76)\end{array}$ & IL-2 & Plasma & $\begin{array}{l}\text { Cytometric bead } \\
\text { array }\end{array}$ & $\begin{array}{l}\text { Outpatients with } \\
\text { chronic } \\
\text { schizophrenia and } \\
\text { healthy controls }\end{array}$ & $\begin{array}{l}29 \text { patients with } \\
\text { schizophrenia; } 26 \\
\text { controls }\end{array}$ & $\begin{array}{l}\text { Differences between } \\
\text { clozapine and other } \\
\text { atypical } \\
\text { antipsychotics was } \\
\text { assessed }\end{array}$ & $\begin{array}{l}\text { IL-2 concentrations were lower } \\
\text { in patients compared to controls. } \\
\text { IL-2 concentrations were } \\
\text { negatively correlated with } \\
\text { PANSS negative subscale score }\end{array}$ \\
\hline Bresee et al. (87) & SIL-2R & Serum & ELISA & $\begin{array}{l}\text { Outpatients with } \\
\text { schizophrenia and } \\
\text { healthy controls }\end{array}$ & $\begin{array}{l}59 \text { patients with } \\
\text { schizophrenia; } 57 \\
\text { controls }\end{array}$ & $\begin{array}{l}\text { Sex, age, smoking, } \\
\text { BMI, type of } \\
\text { pharmacotherapy }\end{array}$ & $\begin{array}{l}\text { SIL-2R concentrations were } \\
\text { elevated in patients compared to } \\
\text { controls. slL-2R concentrations } \\
\text { were correlated with PANSS } \\
\text { negative subscale score }\end{array}$ \\
\hline El Kissi et al. (79) & $\begin{array}{l}\text { IFN- } \gamma \text {,IL- } \\
4, \text { TGF- } \beta \text {, } \\
\text { IL-17, } \\
\text { BAFF }\end{array}$ & Serum & ELISA & $\begin{array}{l}\text { Antipsychotic free } \\
\text { acute inpatients } \\
\text { with schizophrenia } \\
\text { and healthy } \\
\text { controls }\end{array}$ & $\begin{array}{l}60 \text { patients with } \\
\text { schizophrenia; } 28 \\
\text { controls }\end{array}$ & None & $\begin{array}{l}\text { Positive correlation between IFN- } \\
\gamma \text { and SANS total score; } \\
\text { Negative correlation between IL- } \\
17 \text { and SANS total score }\end{array}$ \\
\hline Noto et al. (80) & $\begin{array}{l}\text { CCL11, } \\
\text { CCL24, } \\
\text { MCP-1, } \\
\text { MIP-1 } \alpha, \\
\text { IL-8, IP- } \\
\text { 10, sTNF- } \\
\text { R1, sTNF- } \\
\text { R2, TNF, } \\
\text { IL-2, IL-4, } \\
\text { IL-6, IL- } \\
\text { 10, IFN } \gamma, \\
\text { IL-17 }\end{array}$ & Serum & ELISA & $\begin{array}{l}\text { Outpatients with } \\
\text { schizophrenia and } \\
\text { healthy controls }\end{array}$ & $\begin{array}{l}54 \text { patients with } \\
\text { schizophrenia, } 118 \\
\text { healthy controls }\end{array}$ & $\begin{array}{l}\text { Sex, age, BMl, } \\
\text { smoking, drug/ } \\
\text { alcohol use, } \\
\text { ethnicity, monthly } \\
\text { income (but not } \\
\text { controlled for in all } \\
\text { analyses) }\end{array}$ & $\begin{array}{l}\text { Negative correlation between IL- } \\
2 \text { and PANSS negative subscale } \\
\text { score; Positive correlation } \\
\text { between CCL11 and PANSS } \\
\text { negative score }\end{array}$ \\
\hline
\end{tabular}

CRP, C-Reactive Protein; PANSS, Positive and Negative Syndrome Scale; BMI, body mass index; ELISA, enzyme-linked immunosorbent assay; CDSS, Calgary Depression Scale for Schizophrenia; IL-6, interleukin 6; IFN- $\gamma$, interferon gamma; IL-1 $\beta$, interleukin 1 beta; sIL-2R, soluble interleukin 2 receptor; TNF, tumor necrosis factor; ARMS, at risk mental state; IL-1RA, interleukin 1 receptor antagonist; IL-4, interleukin 4; IL-8, interleukin 8; IL-10, interleukin 10; CHR, clinical high risk; IL-2, interleukin 2; TGF- $\beta$, transforming growth factor beta; IL-17, interleukin 17; BAFF, B cell activating factor of the tumor necrosis factor family; SANS, Scale for the Assessment of Negative Symptoms; CCL11, eotaxin-1; CCL24, eotaxin-2; MCP-1, monocyte chemoattractant protein-1; MIP-1 $\alpha$, macrophage inflammatory protein $1 \alpha$; IP-10, interferon- $\gamma$-inducible protein 10; sTNF-R1, soluble tumor necrosis factor receptor 1 ; sTNFR2, soluble tumor necrosis factor receptor 2.

may play a role in negative symptoms. Moreover, the measurement of a uniform panel of inflammatory markers would allow for comparison of markers across studies and inform the field's understanding of the overall patterns of immune activation relative to these symptoms (65). Two studies in patients with schizophrenia investigated more than one or two individual markers. El Kissi et al. measured five inflammatory/immune markers in acute drug-free patients with schizophrenia and found a positive correlation between interferon-gamma and negative symptoms on the Scale for the Assessment of Negative Symptoms (SANS) and a negative correlation between IL17 and SANS scores (79). Noto and colleagues measured 15 inflammatory/immune biomarkers and found a significant negative relationship between PANSS negative score and IL2 and a positive association with the chemokine CCL11 (80).

\section{NEGATIVE SYMPTOMS AND ANTI- INFLAMMATORY TREATMENT TRIALS}

There is a growing literature on the role of anti-inflammatory treatments in individuals with schizophrenia (97-99). Given the heterogeneity of inflammatory markers in the studies demonstrating relationships with negative symptom severity, blocking inflammation in treatment trials represents a complementary approach to understanding these relationships. The most well-studied anti-inflammatory medications have been the non-steroidal anti-inflammatory medications, including COX-2 inhibitors and aspirin. For example, the COX-2 inhibitor celecoxib showed significant benefit for negative symptoms (in addition to positive and general symptom scores on the PANSS) as an add-on treatment to antipsychotics in a number of studies $(100,101)$. Results from meta-analyses have been mixed depending on which 
studies are included. For example, Muller et al. found benefit for the cyclo-oxygenase-2 (COX-2) inhibitor celecoxib as an adjuvant treatment with the antipsychotic amisulpride on negative symptoms in early stage schizophrenia (101), whereas Rapaport et al. found no such benefit for celecoxib in chronically ill patients treated with either olanzapine or risperidone (102). In metaanalyses, Sommer et al. found a significant benefit for nonsteroidal anti-inflammatory drugs (NSAIDS) for negative symptoms across five studies (103), whereas Nitta et al. did not find a significant benefit for negative symptoms (104). A more recent meta-analysis has demonstrated a significant benefit for NSAIDS in first-episode patients, but not individuals with chronic schizophrenia (105).

Minocycline, a tetracycline antibiotic that has been shown to purportedly be neuroprotective via it's anti-inflammatory and antiapoptotic properties (106), has also been investigated in patients with schizophrenia. A recent meta-analysis demonstrated benefit for minocycline across eight randomized controlled trials (107), although the largest study to date showed no benefit for minocycline for negative symptoms, which was the primary outcome for the study (108). The heterogeneity in results across studies (both individual and meta-analyses) for NSAIDs and minocycline may suggest that there are some individuals who would benefit from anti-inflammatory medications. Individuals with elevated inflammation may represent such a group, as has shown to be the case in patients with depression (109-111), though this was not the case in the recent minocycline trial (108).

\section{THE ROLE OF INFLAMMATION IN REWARD PROCESSING DEFICITS IN PSYCHIATRIC ILLNESS: INSIGHTS INTO NEGATIVE SYMPTOMS}

Deficits in reward processing and decreased motivation have been consistently shown to be present in various psychiatric disorders, including major depressive disorder, bipolar disorder, as well as schizophrenia (112), which have all been shown to have altered peripheral inflammatory marker concentrations (65). The effect of peripheral inflammatory cytokines on the ventral striatum and other regions of the basal ganglia has been linked to deficits in reward processing and decreased motivation (113). Peripheral inflammation alters neural activity in ventral striatal regions following administration of several inflammatory stimuli including interferon (IFN)-alpha, typhoid vaccination, and endotoxin (113-116). Increased inflammation mediates deficits in effort expenditure in studies of laboratory animals and nonhuman primates (117-120). Functional magnetic resonance imaging (fMRI) of subjects with major depressive disorder (MDD) and increased inflammation (as measured by peripheral C-reactive protein; CRP) has been associated with decreased functional connectivity between ventral striatum and ventromedial prefrontal cortex (121). Decreased connectivity between these regions was correlated with decreased motivation and increased peripheral levels of interleukin (IL)-6 and IL-1 receptor antagonist (IL-1RA). The TNF antagonist infliximab has been shown to markedly reduce inflammatory marker concentrations and symptoms of depression, including motivational deficits, in people with major depression with increased inflammation (> $5 \mathrm{mg} / \mathrm{L}$ ) (109).

Patients with schizophrenia who exhibit motivational deficits $(52,60)$, show decreased activation of the ventral striatum to reward anticipation in fMRI tasks, and decreased activation in the ventral striatum has been shown to be inversely correlated with negative symptom severity (36). We believe that these findings as well as the corelative data discussed above suggests that there is an opportunity to employ a transdiagnostic approach studying the effects of inflammation on reward processing and negative symptoms. Recent evidence from Park and colleagues using task-based fMRI begins to identify both similarities and differences in the neural circuit responses to an effort-based reinforcement task for patients with major depression and schizophrenia (122). One transdiagnostic finding that has been similar for subjects with

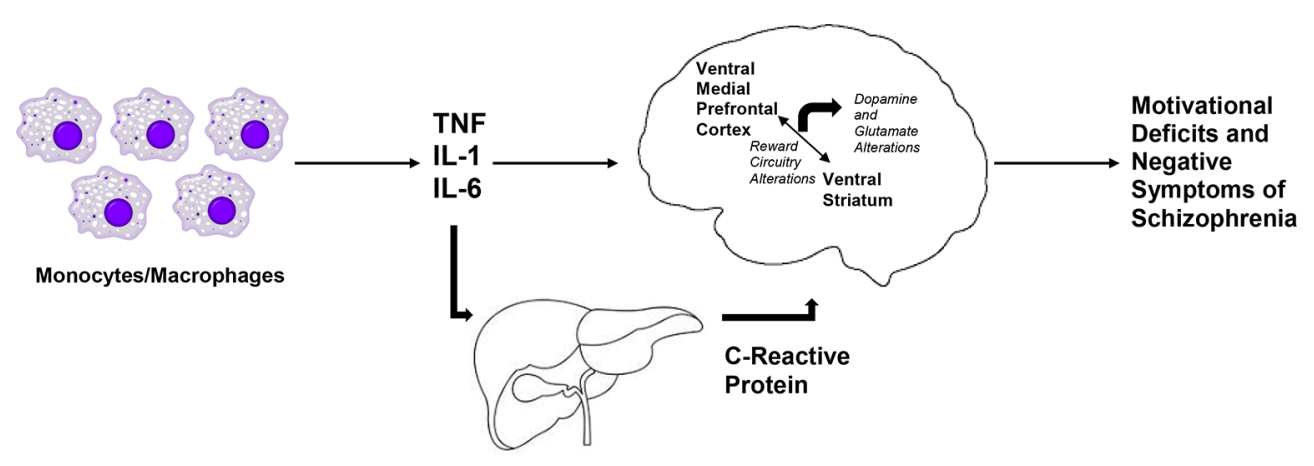

FIGURE 1 | Hypothesized relationship between inflammatory cytokines and negative symptoms of schizophrenia. We hypothesize that markers of inflammation of monocytic origin, such as tumor necrosis factor (TNF), interleukin 1 (IL-1), and interleukin 6 (IL-6) are increased in patients with schizophrenia. Along with the acute phase reactant, C-Reactive Protein (CRP), these inflammatory markers access the brain to lead to decreased activation of the ventral striatum and decreased connectivity in reward-relevant regions of the brain, such as between the ventral striatum and the ventral medial prefrontal cortex. Together with subsequent dysfunction in dopaminergic and glutamatergic signaling, increased inflammation may lead to motivational deficits and negative symptoms in patient with schizophrenia. 
schizophrenia and major depression has been the positive relationship between dopamine transporter availability and the fMRI BOLD response in the nucleus accumbens to reward anticipation has been described in both disorders (123). Individuals at clinical high-risk for schizophrenia from the North American Prodrome Longitudinal Study (NAPLS) cohort have depressive symptoms that have been shown to be associated with negative symptoms (124). This association has also been reported in longitudinal data of patients with schizophrenia extending from the first episode to $10+$ years of chronic psychosis (125). Furthermore, a recent meta-analysis reported a relationship between negative symptoms of schizophrenia and defeatist personal beliefs, a cognitive construct thought to underlie motivational deficits in individuals with depression (126). In summary, neural mechanisms underlying motivational deficits may be similar in depression and in negative symptoms of schizophrenia, and we hypothesize that these findings may reflect the impact of inflammation on reward circuitry across diagnoses (see Figure 1).

\section{INFLAMMATION, DOPAMINERGIC/ GLUTAMATERGIC SIGNALING, AND REWARD CIRCUITRY ALTERATIONS IN SCHIZOPHRENIA}

It is important to note that the majority of studies (including all studies listed in Table 1) measure inflammatory markers in peripheral blood, which raises the question: do similar inflammatory changes also occur centrally in the brain? This is especially important given that inflammatory markers such as CRP and cytokines are large molecules $(\sim 15-25 \mathrm{kD})$ and are not freely able to cross the blood brain barrier (BBB). These markers are able to access the brain to activate local inflammatory markers via a number of different mechanisms including 1) movement through leaky parts of the $\mathrm{BBB}, 2$ ) active uptake via transporter systems, 3) activation of endothelial and immune cells in cerebral vasculature and subsequent release of inflammatory markers in the brain, and 4) via peripheral afferents, such as the vagus nerve, that may relay cytokine signals to the brain (127-129). One piece of evidence that suggests similar changes in inflammatory marker concentrations are occurring centrally comes from studies measuring cerebrospinal fluid (CSF) which demonstrate similar patterns in inflammatory marker concentrations in patients with schizophrenia relative to healthy controls $(130,131)$. Recent evidence in patients with major depressive disorder demonstrates that peripheral CRP and inflammatory cytokines are strongly correlated with CSF markers, which suggests that peripheral markers may reflect similar findings in the central nervous system (132).

Inflammation leads to decreases in dopamine release and increased glutamate activity in some patients with depression and this has been correlated with reward processing and motivational deficits $(112,133)$. Inflammation impacts dopaminergic and glutamatergic signaling via a variety of potential mechanisms (134). Inflammation decreases dopamine availability and dopamine release (135), and may decrease concentrations of tetrahydrobiopterin, a necessary co-factor in dopamine synthesis (136). Similarly, proinflammatory cytokines decease glutamate transporter expression on the cell surface of astrocytes and induce glutamate release. Proinflammatory cytokines also modulate the kynurenine pathway, leading to increased quinolinic acid release from microglia, which binds to $\mathrm{N}$-methyl-D-aspartate (NMDA) receptors and can stimulate glutamate release and block reuptake from astrocytes (137).

Dopaminergic and glutamatergic dysfunction has been postulated to be central to the underlying pathophysiology of schizophrenia, with putative hyperdopaminergic states in subcortical regions as well as NMDA-receptor hypofunction (138-140). Dopaminergic and glutamatergic signaling have also been consistently implicated in reward processing and effort cost computation in healthy subjects and individuals with schizophrenia $(29,46,53,141-145)$. Evidence suggests downstream effects of dopamine and glutamate on connectivity in brain circuitry in patients with schizophrenia $(146,147)$ including disrupted resting state networks $(148,149)$.

As expected in a heterogeneous syndrome such as schizophrenia and given the complex circuit-dependent actions of neurotransmitters, some studies (150, 151), have demonstrated that individuals with treatment resistant schizophrenia, who may have persistent negative symptoms $(16,152)$, may have decreased dopamine synthesis capacity. This is further supported by recent evidence that phase of illness and antipsychotic medications may alter dopaminergic tone by increasing presynaptic dopamine capacity (153). As such, there may be heterogeneity in dopamine signaling pathways such that the underlying hyperdopaminergic state in subcortical regions, which was long thought to be the field's understanding of dopamine signaling in patients with schizophrenia (154), may only be present in a subgroup of patients. Other patients may have hypodopaminergic signaling in these regions, as reflected by decreased presynaptic dopamine synthesis capacity. These patients may also have different glutamatergic signaling profiles suggestive of a different underlying neurobiology. In fact, there is recent evidence demonstrating increased glutamatergic signaling in the anterior cingulate of treatment resistant patients with schizophrenia compared to antipsychotic responsive patients with schizophrenia (155). Thus, there seems to be a complex and possibly circuit specific interplay between dopamine, glutamate, and potentially other neurotransmitters. It is possible that known effects of inflammation on dopamine and glutamate signaling could be responsible for at least one of the different neurotransmitter signaling profiles that have been described 
in patients with schizophrenia. Future work will be necessary to test this hypothesis as it relates to inflammation and dopamine/glutamate signaling in patients with schizophrenia.

\section{INFLAMMATION AND NEGATIVE SYMPTOMS: FUTURE DIRECTIONS}

Despite effective treatments that target positive symptoms of schizophrenia, the treatment of negative symptoms remains a challenge; this is particularly important since negative symptoms are responsible for significant disability and poor function $(24,156,157)$. Multiple pathophysiologic mechanisms outside of traditional dopamine- 2 antagonism have been studied in an attempt to palliate negative symptoms, including alpha-7 nicotinic agonists/partial agonists, D-amino acid oxidase inhibitors, NMDA receptor glycine site antagonists, glycine transporter 1 inhibitors, mGluR2/3 positive allosteric modulators, muscarinic acetylcholine agonists, and amphetamine based compounds, with limited success (24). More recent strategies to target negative symptoms include modulating cyclic guanosine monophosphate (cGMP) (158), trace amine-associated receptor 1 (TAAR1) agonists (159), cannabidiol (160) but are in early phases of development (161).

Some of these novel strategies may involve pathways that impact the immune system. Given increasing recognition of the role that the immune system plays in schizophrenia (162), future work should seek to understand the mechanism by which the immune system, and specifically inflammation, may impact the brain to lead to negative symptoms of schizophrenia. Work in depression may serve as a model to test hypotheses regarding these mechanisms. For example, much of the work in depression has focused on inflammation's impact on anhedonia and motivational deficits. Although both are core negative symptoms in patients with schizophrenia, it is unclear whether other negative symptoms, such as deficits in affect may also be driven by inflammatory mediators. Future work may be aided by using some of the more recently developed negative symptoms scales, such as the Brief Negative Symptom Scale (163) or the Clinical Assessment Interview for Negative Symptoms (164), which have separate subscales that reflect deficits in affect and deficits in motivation. These scales may allow for the greater differentiation of negative symptoms from depression. Moreover, scales that directly address motivation, such as the Motivation and Pleasure Scale (165) may be a more specific outcome measure. Similarly, behavioral tasks that directly assess effort-based motivation (166) have been shown to be sensitive to the effects of inflammation (167) as well to deficits and negative symptoms in patients with schizophrenia $(47,53,55,168)$.

In order to better investigate relationships between inflammation and negative symptoms, the field must move away from simple correlations between measured inflammatory markers and negative symptoms. Due to the heterogeneity in clinical presentations of schizophrenia, focusing on those symptoms that are known to be targeted by the effects of inflammation would represent a hypothesis-driven approach. The impact of peripheral inflammation on the brain appears to be an evolutionarily conserved process (169) via effects on the basal ganglia, dopamine signaling, and subsequent motivational deficits. Focusing on these deficits and on the impact of inflammation on the basal ganglia using neuroimaging strategies could provide evidence suggesting that a similar process occurs in patients with persistence of negative symptoms of schizophrenia. For example, studies may choose to compare patients with high versus low inflammation [i.e., CRP cutoffs based on American Heart Association/Center for Disease Control and Prevention guidelines (170)] or high versus low negative symptom severity. This may partially explain seemingly negative findings from treatment trials using cytokine antagonists, such as a recent study that showed no benefit from tocilizumab, an anti-IL-6 receptor antagonist (171). Approaches such as stratifying patients based on a marker such as CRP, as has been done in depression $(109,111,172)$, should be considered in treatment trials in patients with schizophrenia. Moreover, in order to disentangle heterogeneity, considering phase of illness will be important as well. Given known differences in inflammatory marker concentrations in individuals at clinical high risk, first episode psychosis, acute psychosis, and chronic schizophrenia, studying a heterogeneous group of patients who are at different phases of illness may obscure important biological findings $(65,173-175)$. Similarly, designing longitudinal studies to measure inflammatory cytokines over time and phase of illness are essential for investigating the trajectory of negative symptom and functioning.

Another important consideration is the need for agreement about which inflammatory markers to measure and what assay platform to use: this would facilitate greater reproducibility and comparison across studies. Studying patterns of immune activation with a uniform panel of markers also allows the field to create more reliable ratios of pro-inflammatory to anti-inflammatory markers (e.g., TNF : IL-10) which may provide more useful insights into the role these cytokines play in the pathophysiology of the symptoms compared to individual cytokines alone.

Increasingly, inflammatory markers such as IL-6, largely thought to be pro-inflammatory, has been shown to be pleiotropic in nature and may even have anti-inflammatory properties (176). Furthermore, individual differences in the expression and regulation of these inflammatory markers is complex and may lead to different behavioral effects $(177,178)$. The field must also consider and agree upon a common set of variables to control for in analyses that could confound the relationship between inflammation and brain regions/circuits and behavior. For example, sex, BMI, or other measures of insulin resistance, smoking, illicit drug use, antipsychotic exposure, stage of illness, and education or other proxy of socioeconomic status have all been shown to be associated with alterations in inflammatory molecules $(65,179)$. Variables related to metabolism/insulin resistance are important and have been demonstrated to be important even for 
drug-naïve first episode and clinical high-risk individuals who have been shown to have alterations in metabolic markers at the first episode (180). Collaborations with immunologists may help us better understanding the role these markers play and allow for more nuance in interpretation of the growing data in this field.

Outstanding questions also remain regarding how inflammation may impact dopaminergic and glutamatergic systems. In healthy controls exposed to inflammatory stimuli and in patients with depression, inflammation appears to decrease dopaminergic signaling $(112,115,181)$ and increased glutamate in subcortical regions $(133,182)$. How these putative mechanisms alter known dopaminergic and glutamatergic abnormalities in patients with schizophrenia is an important question that must be addressed. Furthermore, understanding the interplay of the immune system with metabolism $(180,183,184)$ or the kynurenine pathway $(185$, 186) may offer an approach to understand the complexities of how the immune system may impact the brain in patients with schizophrenia to lead to negative symptoms. Strategies such as challenges with drugs that target inflammation and/or these neurotransmitter systems, neuroimaging approaches such as positron emission tomography (PET) or magnetic resonance spectroscopy (MRS) or perhaps using novel approaches such as induced pluripotent stem cells (iPSC) from patients with schizophrenia may help elucidate these mechanisms.

Novel approaches to understand and treat negative symptoms of schizophrenia are of paramount importance.

\section{REFERENCES}

1. Goeree R, Farahati F, Burke N, Blackhouse G, O'Reilly D, Pyne J, et al. The economic burden of schizophrenia in Canada in 2004. Curr Med Res Opin (2005) 21(12):2017-28. doi: 10.1185/030079905X75087

2. McEvoy JP. The costs of schizophrenia. J Clin Psychiatry (2007) 68(Suppl 14):4-7.

3. Suzuki T, Remington G, Mulsant BH, Uchida H, Rajji TK, Graff-Guerrero A, et al. Defining treatment-resistant schizophrenia and response to antipsychotics: a review and recommendation. Psychiatry Res (2012) 197(12):1-6. doi: 10.1016/j.psychres.2012.02.013

4. Kennedy JL, Altar CA, Taylor DL, Degtiar I, Hornberger JC. The social and economic burden of treatment-resistant schizophrenia: a systematic literature review. Int Clin Psychopharmacol (2014) 29(2):63-76. doi: 10.1097/ YIC.0b013e32836508e6

5. Murray CJ, Lopez AD. Alternative projections of mortality and disability by cause 1990-2020: global burden of disease study. Lancet (1997) 349 (9064):1498-504. doi: 10.1016/S0140-6736(96)07492-2

6. Kooyman I, Dean K, Harvey S, Walsh E. Outcomes of public concern in schizophrenia. Br J Psychiatry Suppl (2007) 50:s29-36. doi: 10.1192/ bjp.191.50.s29

7. Marwaha S, Johnson S. Schizophrenia and employment - a review. Soc Psychiatry Psychiatr Epidemiol (2004) 39(5):337-49. doi: 10.1007/s00127004-0762-4

8. Foster A, Gable J, Buckley J. Homelessness in schizophrenia. Psychiatr Clin North Am (2012) 35(3):717-34. doi: 10.1016/j.psc.2012.06.010

9. Laursen TM, Nordentoft M, Mortensen PB. Excess early mortality in schizophrenia. Annu Rev Clin Psychol (2014) 10:425-48. doi: 10.1146/ annurev-clinpsy-032813-153657

10. Kirkpatrick B, Fenton WS, Carpenter WTJr., Marder SR. The NIMHMATRICS consensus statement on negative symptoms. Schizophr Bull (2006) 32(2):214-9. doi: 10.1093/schbul/sbj053
The immune system has been implicated in the pathophysiology of schizophrenia and previous studies of psychopathology and anti-inflammatory trials offer clues to the possibility that the immune system may underlie negative symptoms of the disorder. The role of the immune system in depression offers important and intriguing hypotheses as to the mechanism behind inflammations and negative symptoms via its impact on basal ganglia regions and neurotransmitter systems. Similar approaches should be undertaken in patients with schizophrenia to investigate whether these mechanisms are transdiagnostic. Given the burden of negative symptoms on patients with schizophrenia, further understanding the impact of the immune system on these symptoms is of great necessity.

\section{AUTHOR CONTRIBUTIONS}

DG conducted the literature review. Both DG and MR conceptualized, wrote, and edited the manuscript.

\section{FUNDING}

DG is supported by a NIMH K23 MH114037, NIMH L30 MH114414.
11. Strauss GP, Horan WP, Kirkpatrick B, Fischer BA, Keller WR, Miski P, et al. Deconstructing negative symptoms of schizophrenia: avolition-apathy and diminished expression clusters predict clinical presentation and functional outcome. J Psychiatr Res (2013) 47(6):783-90. doi: 10.1016/ j.jpsychires.2013.01.015

12. Bobes J, Arango C, Garcia-Garcia M, Rejas J. Prevalence of negative symptoms in outpatients with schizophrenia spectrum disorders treated with antipsychotics in routine clinical practice: findings from the CLAMORS study. J Clin Psychiatry (2010) 71(3):280-6. doi: 10.4088/JCP.08m04250yel

13. Szkultecka-Debek M, Walczak J, Augustynska J, Miernik K, Stelmachowski J, Pieniazek I, et al. Epidemiology and treatment guidelines of negative symptoms in schizo-phrenia in central and eastern europe: a literature review. Clin Pract Epidemiol Ment Health (2015) 11:158-65. doi: 10.2174/1745017901511010158

14. Kirkpatrick B, Buchanan RW, Ross DE, Carpenter WTJr. A separate disease within the syndrome of schizophrenia. Arch Gen Psychiatry (2001) 58 (2):165-71. doi: 10.1001/archpsyc.58.2.165

15. Kirkpatrick B, Galderisi S. Deficit schizophrenia: an update. World Psychiatry (2008) 7(3):143-7. doi: 10.1002/j.2051-5545.2008.tb00181.x

16. Caspi A, Davidson M, Tamminga CA. Treatment-refractory schizophrenia. Dialogues Clin Neurosci (2004) 6(1):61-70.

17. Iasevoli F, Avagliano C, Altavilla B, Barone A, D'Ambrosio L, Matrone M, et al. Disease severity in treatment resistant schizophrenia patients is mainly affected by negative symptoms, which mediate the effects of cognitive dysfunctions and neurological soft signs. Front Psychiatry (2018) 9:553. doi: 10.3389/fpsyt.2018.00553

18. Rapaport MH, Bazzetta J, McAdams LA, Patterson T, Jeste DV. Validation of the scale of functioning in older outpatients with schizophrenia. Am J Geriatr Psychiatry (1996) 4(3):218-28. doi: 10.1097/00019442-19962243000005

19. Leifker FR, Bowie CR, Harvey PD. Determinants of everyday outcomes in schizophrenia: the influences of cognitive impairment, functional capacity, 
and symptoms. Schizophr Res (2009) 115(1):82-7. doi: 10.1016/ j.schres.2009.09.004

20. Harvey PD. Assessment of everyday functioning in schizophrenia: implications for treatments aimed at negative symptoms. Schizophr Res (2013) 150(2-3):353-5. doi: 10.1016/j.schres.2013.04.022

21. Fervaha G, Foussias G, Agid O, Remington G. Motivational and neurocognitive deficits are central to the prediction of longitudinal functional outcome in schizophrenia. Acta Psychiatr Scand (2014) 130 (4):290-9. doi: 10.1111/acps.12289

22. Green MF, Llerena K, Kern RS. The "right stuff" revisited: what have we learned about the determinants of daily functioning in schizophrenia? Schizophr Bull (2015) 41(4):781-5. doi: 10.1093/schbul/sbv018

23. Carbon M, Correll CU. Thinking and acting beyond the positive: the role of the cognitive and negative symptoms in schizophrenia. CNS Spectr (2014) 19 Suppl 1:38-52; quiz 35-37, 53. doi: 10.1017/S1092852914000601

24. Davis MC, Horan WP, Marder SR. Psychopharmacology of the negative symptoms: current status and prospects for progress. Eur Neuropsychopharmacol (2014) 24(5):788-99. doi: 10.1016/j.euroneuro.2013.10.010

25. Blanchard JJ, Cohen AS. The structure of negative symptoms within schizophrenia: implications for assessment. Schizophr Bull (2006) 32 (2):238-45. doi: 10.1093/schbul/sbj013

26. Strauss GP, Harrow M, Grossman LS, Rosen C. Periods of recovery in deficit syndrome schizophrenia: a 20-year multi-follow-up longitudinal study. Schizophr Bull (2010) 36(4):788-99. doi: 10.1093/schbul/sbn167

27. Horan WP, Kring AM, Gur RE, Reise SP, Blanchard JJ. Development and psychometric validation of the clinical assessment interview for negative symptoms (CAINS). Schizophr Res (2011) 132(2-3):140-5. doi: 10.1016/ j.schres.2011.06.030

28. Strauss GP, Hong LE, Gold JM, Buchanan RW, McMahon RP, Keller WR, et al. Factor structure of the brief negative symptom scale. Schizophr Res (2012) 142(1-3):96-8. doi: 10.1016/j.schres.2012.09.007

29. Strauss GP, Waltz JA, Gold JM. A review of reward processing and motivational impairment in schizophrenia. Schizophr Bull (2014) 40 Suppl 2:S107-116. doi: 10.1093/schbul/sbt197

30. Insel T, Cuthbert B, Garvey M, Heinssen R, Pine DS, Quinn K, et al. Research domain criteria (RDoC): toward a new classification framework for research on mental disorders. Am J Psychiatry (2010) 167(7):748-51. doi: 10.1176/appi.ajp.2010.09091379

31. Cuthbert BN. Research domain criteria: toward future psychiatric nosologies. Dialogues Clin Neurosci (2015) 17(1):89-97.

32. Barch DM, Pagliaccio D, Luking K. Mechanisms underlying motivational deficits in psychopathology: similarities and differences in depression and schizophrenia. Curr Top Behav Neurosci (2016) 27:411-49. doi: 10.1007/ 7854_2015_376

33. Wise RA. Brain reward circuitry: insights from unsensed incentives. Neuron (2002) 36(2):229-40. doi: 10.1016/S0896-6273(02)00965-0

34. Russo SJ, Nestler EJ. The brain reward circuitry in mood disorders. Nat Rev Neurosci (2013) 14(9):609-25. doi: 10.1038/nrn3381

35. Juckel G, Schlagenhauf F, Koslowski M, Filonov D, Wustenberg T, Villringer A, et al. Dysfunction of ventral striatal reward prediction in schizophrenic patients treated with typical, not atypical, neuroleptics. Psychopharmacol (Berl) (2006a) 187(2):222-8. doi: 10.1007/s00213-006-0405-4

36. Juckel G, Schlagenhauf F, Koslowski M, Wustenberg T, Villringer A, Knutson B, et al. Dysfunction of ventral striatal reward prediction in schizophrenia. Neuroimage (2006b) 29(2):409-16. doi: 10.1016/ j.neuroimage.2005.07.051

37. Juckel G, Friedel E, Koslowski M, Witthaus H, Ozgurdal S, Gudlowski Y, et al. Ventral striatal activation during reward processing in subjects with ultra-high risk for schizophrenia. Neuropsychobiology (2012) 66(1):50-6. doi: $10.1159 / 000337130$

38. Nielsen MO, Rostrup E, Wulff S, Bak N, Lublin H, Kapur S, et al. Alterations of the brain reward system in antipsychotic naive schizophrenia patients. Biol Psychiatry (2012) 71(10):898-905. doi: 10.1016/j.biopsych.2012.02.007

39. Reiss JP, Campbell DW, Leslie WD, Paulus MP, Ryner LN, Polimeni JO, et al. Deficit in schizophrenia to recruit the striatum in implicit learning: a functional magnetic resonance imaging investigation. Schizophr Res (2006) 87(1-3):127-37. doi: 10.1016/j.schres.2006.04.027
40. Weickert TW, Goldberg TE, Callicott JH, Chen Q, Apud JA, Das S, et al. Neural correlates of probabilistic category learning in patients with schizophrenia. J Neurosci (2009) 29(4):1244-54. doi: 10.1523/ JNEUROSCI.4341-08.2009

41. Murray GK, Corlett PR, Clark L, Pessiglione M, Blackwell AD, Honey G, et al. Substantia nigra/ventral tegmental reward prediction error disruption in psychosis. Mol Psychiatry (2008) 13239(3):267-76. doi: 10.1038/ sj.mp. 4002058

42. Schlagenhauf F, Sterzer P, Schmack K, Ballmaier M, Rapp M, Wrase J, et al. Reward feedback alterations in unmedicated schizophrenia patients: relevance for delusions. Biol Psychiatry (2009) 65(12):1032-9. doi: 10.1016/j.biopsych.2008.12.016

43. Morris RW, Vercammen A, Lenroot R, Moore L, Langton JM, Short B, et al. Disambiguating ventral striatum fMRI-related BOLD signal during reward prediction in schizophrenia. Mol Psychiatry (2012) 17235(3):280-39. doi: 10.1038/mp.2011.75

44. Segarra N, Metastasio A, Ziauddeen H, Spencer J, Reinders NR, Dudas RB, et al. Abnormal frontostriatal activity during unexpected reward receipt in depression and schizophrenia: relationship to anhedonia. Neuropsychopharmacology (2016) 41(8):2001-10. doi: 10.1038/npp.2015.370

45. Fervaha G, Graff-Guerrero A, Zakzanis KK, Foussias G, Agid O, Remington G. Incentive motivation deficits in schizophrenia reflect effort computation impairments during cost-benefit decision-making. J Psychiatr Res (2013) 47(11):1590-6. doi: 10.1016/j.jpsychires.2013.08.003

46. Gold JM, Strauss GP, Waltz JA, Robinson BM, Brown JK, Frank MJ. Negative symptoms of schizophrenia are associated with abnormal effortcost computations. Biol Psychiatry (2013) 74(2):130-6. doi: 10.1016/ j.biopsych.2012.12.022

47. Barch DM, Treadway MT, Schoen N. Effort, anhedonia, and function in schizophrenia: reduced effort allocation predicts amotivation and functional impairment. J Abnorm Psychol (2014) 123(2):387-97. doi: 10.1037/a0036299

48. Wolf DH, Satterthwaite TD, Kantrowitz JJ, Katchmar N, Vandekar L, Elliott MA, et al. Amotivation in schizophrenia: integrated assessment with behavioral, clinical, and imaging measures. Schizophr Bull (2014a) 40 (6):1328-37. doi: 10.1093/schbul/sbu026

49. Docx L, de la Asuncion J, Sabbe B, Hoste L, Baeten R, Warnaerts N, et al. Effort discounting and its association with negative symptoms in schizophrenia. Cognit Neuropsychiatry (2015) 20(2):172-85. doi: 10.1080/ 13546805.2014.993463

50. Fervaha G, Duncan M, Foussias G, Agid O, Faulkner GE, Remington G. Effort-based decision making as an objective paradigm for the assessment of motivational deficits in schizophrenia. Schizophr Res (2015) 168(1-2):48390. doi: 10.1016/j.schres.2015.07.023

51. Hartmann MN, Hager OM, Reimann AV, Chumbley JR, Kirschner M, Seifritz E, et al. Apathy but not diminished expression in schizophrenia is associated with discounting of monetary rewards by physical effort. Schizophr Bull (2015) 41(2):503-12. doi: 10.1093/schbul/sbu102

52. Reddy LF, Horan WP, Barch DM, Buchanan RW, Dunayevich E, Gold JM, et al. Effort-based decision-making paradigms for clinical trials in schizophrenia: part 1-psychometric characteristics of 5 paradigms. Schizophr Bull (2015) 41(5):1045-54. doi: 10.1093/schbul/sbv089

53. Treadway MT, Peterman JS, Zald DH, Park S. Impaired effort allocation in patients with schizophrenia. Schizophr Res (2015) 161(2-3):382-5. doi: 10.1016/j.schres.2014.11.024

54. Wang J, Huang J, Yang XH, Lui SS, Cheung EF, Chan RC. Anhedonia in schizophrenia: deficits in both motivation and hedonic capacity. Schizophr Res (2015) 168(1-2):465-74. doi: 10.1016/j.schres.2015.06.019

55. McCarthy JM, Treadway MT, Bennett ME, Blanchard JJ. Inefficient effort allocation and negative symptoms in individuals with schizophrenia. Schizophr Res (2016) 170(2-3):278-84. doi: 10.1016/j.schres.2015.12.017

56. Strauss GP, Whearty KM, Morra LF, Sullivan SK, Ossenfort KL, Frost KH. Avolition in schizophrenia is associated with reduced willingness to expend effort for reward on a progressive ratio task. Schizophr Res (2016) 170 (1):198-204. doi: 10.1016/j.schres.2015.12.006

57. McClure SM, York MK, Montague PR. The neural substrates of reward processing in humans: the modern role of FMRI. Neuroscientist (2004) 10 (3):260-8. doi: $10.1177 / 1073858404263526$ 
58. Salamone JD, Correa M, Farrar A, Mingote SM. Effort-related functions of nucleus accumbens dopamine and associated forebrain circuits. Psychopharmacol (Berl) (2007) 191(3):461-82. doi: 10.1007/ s00213-006-0668-9

59. Treadway MT, Zald DH. Parsing anhedonia: translational models of rewardprocessing deficits in psychopathology. Curr Dir Psychol Sci (2013) 22 (3):244-9. doi: 10.1177/0963721412474460

60. Horan WP, Reddy LF, Barch DM, Buchanan RW, Dunayevich E, Gold JM, et al. Effort-based decision-making paradigms for clinical trials in schizophrenia: part 2-external validity and correlates. Schizophr Bull (2015) 41(5):1055-65. doi: 10.1093/schbul/sbv090

61. Vanes LD, Mouchlianitis E, Collier T, Averbeck BB, Shergill SS. Differential neural reward mechanisms in treatment-responsive and treatment-resistant schizophrenia. Psychol Med (2018) 48(14):2418-27. doi: 10.1017/ S0033291718000041

62. Tamminga CA, Ivleva EI, Keshavan MS, Pearlson GD, Clementz BA, Witte $\mathrm{B}$, et al. Clinical phenotypes of psychosis in the Bipolar-Schizophrenia Network on Intermediate Phenotypes (B-SNIP). Am J Psychiatry (2013) 170(11):1263-74. doi: 10.1176/appi.ajp.2013.12101339

63. Lang FU, Walther S, Stegmayer K, Anderson-Schmidt H, Schulze TG, Becker T, et al. Subtyping schizophrenia: a comparison of positive/ negative and system-specific approaches. Compr Psychiatry (2015) 61:11521. doi: 10.1016/j.comppsych.2015.05.014

64. Bosia M, Bechi M, Bosinelli F, Politi E, Buonocore M, Spangaro M, et al. From cognitive and clinical substrates to functional profiles: disentangling heterogeneity in schizophrenia. Psychiatry Res (2019) 271:446-53. doi: 10.1016/j.psychres.2018.12.026

65. Goldsmith DR, Rapaport MH, Miller BJ. A meta-analysis of blood cytokine network alterations in psychiatric patients: comparisons between schizophrenia, bipolar disorder and depression. Mol Psychiatry (2016) 21 (12):1696-709. doi: $10.1038 / \mathrm{mp} .2016 .3$

66. Brown AS, Derkits EJ. Prenatal infection and schizophrenia: a review of epidemiologic and translational studies. Am J Psychiatry (2010) 167(3):26180. doi: 10.1176/appi.ajp.2009.09030361

67. Khandaker GM, Zimbron J, Dalman C, Lewis G, Jones PB. Childhood infection and adult schizophrenia: a meta-analysis of population-based studies. Schizophr Res (2012) 139(1-3):161-8. doi: 10.1016/ j.schres.2012.05.023

68. Khandaker GM, Zimbron J, Lewis G, Jones PB. Prenatal maternal infection, neurodevelopment and adult schizophrenia: a systematic review of population-based studies. Psychol Med (2013) 43(2):239-57. doi: 10.1017/ S0033291712000736

69. Eaton WW, Byrne M, Ewald H, Mors O, Chen CY, Agerbo E, et al. Association of schizophrenia and autoimmune diseases: linkage of Danish national registers. Am J Psychiatry (2006) 163(3):521-8. doi: 10.1176/ appi.ajp.163.3.521

70. Benros ME, Nielsen PR, Nordentoft M, Eaton WW, Dalton SO, Mortensen $\mathrm{PB}$. Autoimmune diseases and severe infections as risk factors for schizophrenia: a 30-year population-based register study. Am J Psychiatry (2011) 168(12):1303-10. doi: 10.1176/appi.ajp.2011.11030516

71. Shi J, Levinson DF, Duan J, Sanders AR, Zheng Y, Pe'er I, et al. Common variants on chromosome 6 p22.1 are associated with schizophrenia. Nature (2009) 460(7256):753-7. doi: 10.1038/nature08192

72. Ripke S, Neale BM, Corvin A, Walters JT, Farh KH, Holmans PA, et al. Biological insights from 108 schizophrenia-associated genetic loci. Nature (2014) 511(7510):421-7. doi: 10.1038/nature13595

73. Andreassen OA, Harbo HF, Wang Y, Thompson WK, Schork AJ, Mattingsdal M, et al. Genetic pleiotropy between multiple sclerosis and schizophrenia but not bipolar disorder: differential involvement of immunerelated gene loci. Mol Psychiatry (2015) 20(2):207-14. doi: 10.1038/ mp.2013.195

74. Sekar A, Bialas AR, de Rivera H, Davis A, Hammond TR, Kamitaki N, et al. Schizophrenia risk from complex variation of complement component 4. Nature (2016) 530(7589):177-83. doi: 10.1038/nature16549

75. Garcia-Rizo C, Fernandez-Egea E, Oliveira C, Justicia A, Bernardo M, Kirkpatrick B. Inflammatory markers in antipsychotic-naive patients with nonaffective psychosis and deficit vs. nondeficit features. Psychiatry Res (2012) 198(2):212-5. doi: 10.1016/j.psychres.2011.08.014
76. Asevedo E, Rizzo LB, Gadelha A, Mansur RB, Ota VK, Berberian AA, et al. Peripheral interleukin-2 level is associated with negative symptoms and cognitive performance in schizophrenia. Physiol Behav (2014) 129:194-8. doi: 10.1016/j.physbeh.2014.02.032

77. Stojanovic A, Martorell L, Montalvo I, Ortega L, Monseny R, Vilella E, et al. Increased serum interleukin-6 levels in early stages of psychosis: associations with at-risk mental states and the severity of psychotic symptoms. Psychoneuroendocrinology (2014) 41:23-32. doi: 10.1016/j.psyneuen. 2013.12.005

78. Xiu MH, Yang GG, Tan YL, Chen DC, Tan SP, Wang ZR, et al. Decreased interleukin-10 serum levels in first-episode drug-naive schizophrenia: relationship to psychopathology. Schizophr Res (2014) 156(1):9-14. doi: 10.1016/j.schres.2014.03.024

79. El Kissi Y, Samoud S, Mtiraoui A, Letaief L, Hannachi N, Ayachi M, et al. Increased Interleukin-17 and decreased BAFF serum levels in drug-free acute schizophrenia. Psychiatry Res (2015) 225(1-2):58-63. doi: 10.1016/ j.psychres.2014.10.007

80. Noto C, Maes M, Ota VK, Teixeira AL, Bressan RA, Gadelha A, et al. High predictive value of immune-inflammatory biomarkers for schizophrenia diagnosis and association with treatment resistance. World J Biol Psychiatry (2015) 16(6):422-9. doi: 10.3109/15622975.2015.1062552

81. Fan X, Pristach C, Liu EY, Freudenreich O, Henderson DC, Goff DC. Elevated serum levels of C-reactive protein are associated with more severe psychopathology in a subgroup of patients with schizophrenia. Psychiatry Res (2007) 149(1-3):267-71. doi: 10.1016/j.psychres.2006.07.011

82. Boozalis T, Teixeira AL, Cho RY-J, Okusaga O. C-reactive protein correlates with negative symptoms in patients with schizophrenia. Front Public Health (2018) 5(360)1-6. doi: 10.3389/fpubh.2017.00360

83. Liemburg EJ, Nolte IM, Klein HC, Knegtering H. Relation of inflammatory markers with symptoms of psychotic disorders: a large cohort study. Prog Neuropsychopharmacol Biol Psychiatry (2018) 86:89-94. doi: 10.1016/ j.pnpbp.2018.04.006

84. Goldsmith DR, Haroon E, Miller AH, Strauss GP, Buckley PF, Miller BJ. TNF-alpha and IL-6 are associated with the deficit syndrome and negative symptoms in patients with chronic schizophrenia. Schizophr Res (2018) 199:281-4. doi: 10.1016/j.schres.2018.02.048

85. Goldsmith DR, Haroon E, Miller AH, Addington J, Bearden C, Cadenhead $\mathrm{K}$, et al. Association of baseline inflammatory markers and the development of negative symptoms in individuals at clinical high risk for psychosis. Brain Behav Immun (2019) 76:268-74. doi: 10.1016/ j.bbi.2018.11.315

86. Zhu F, Zhang L, Liu F, Wu R, Guo W, Ou J, et al. Altered serum tumor necrosis factor and interleukin-lbeta in first-episode drug-naive and chronic schizophrenia. Front Neurosci (2018) 12:296. doi: 10.3389/fnins.2018.00296

87. Bresee C, Rapaport MH. Persistently increased serum soluble interleukin-2 receptors in continuously ill patients with schizophrenia. Int $J$ Neuropsychopharmacol (2009) 12(6):861-5. doi: 10.1017/S1461145709000315

88. Marnell L, Mold C, Du Clos TW. C-reactive protein: ligands, receptors and role in inflammation. Clin Immunol (2005) 117(2):104-11. doi: 10.1016/ j.clim.2005.08.004

89. Sproston NR, Ashworth JJ. Role of c-reactive protein at sites of inflammation and infection. Front Immunol (2018) 9:754. doi: 10.3389/fimmu.2018.00754

90. Miller BJ, Culpepper N, Rapaport MH. C-reactive protein levels in schizophrenia: a review and meta-analysis. Clin Schizophr Relat Psychoses (2014) 7(4):223-30. doi: 10.3371/CSRP.MICU.020813

91. Fernandes BS, Steiner J, Bernstein HG, Dodd S, Pasco JA, Dean OM, et al. Creactive protein is increased in schizophrenia but is not altered by antipsychotics: meta-analysis and implications. Mol Psychiatry (2016) 21 (4):554-64. doi: 10.1038/mp.2015.87

92. Kirkpatrick B, Mucci A, Galderisi S. Primary, enduring negative symptoms: an update on research. Schizophr Bull (2017) 43(4):730-6. doi: 10.1093/ schbul/sbx064

93. Rose-John S, Winthrop K, Calabrese L. The role of IL-6 in host defence against infections: immunobiology and clinical implications. Nat Rev Rheumatol (2017) 13(7):399-409. doi: 10.1038/nrrheum.2017.83

94. Del Giudice M, Gangestad SW. Rethinking IL-6 and CRP: Why they are more than inflammatory biomarkers, and why it matters. Brain Behav Immun (2018) 70:61-75. doi: 10.1016/j.bbi.2018.02.013 
95. Scheller J, Chalaris A, Schmidt-Arras D, Rose-John S. The pro- and antiinflammatory properties of the cytokine interleukin-6. Biochim Biophys Acta (2011) 1813(5):878-88. doi: 10.1016/j.bbamcr.2011.01.034

96. Wolf J, Rose-John S, Garbers C. Interleukin-6 and its receptors: a highly regulated and dynamic system. Cytokine (2014b) 70(1):11-20. doi: 10.1016/ j.cyto.2014.05.024

97. Muller N. Inflammation in schizophrenia: pathogenetic aspects and therapeutic considerations. Schizophr Bull (2018) 44(5):973-82. doi: $10.1093 /$ schbul/sby024

98. Cakici N, van Beveren NJM, Judge-Hundal G, Koola MM, Sommer IEC. An update on the efficacy of anti-inflammatory agents for patients with schizophrenia: a meta-analysis. Psychol Med (2019) 49(14):2307-19. doi: 10.1017/S0033291719001995

99. Pandurangi AK, Buckley PF. Inflammation, antipsychotic drugs, and evidence for effectiveness of anti-inflammatory agents in schizophrenia. Curr Top Behav Neurosci (2019) 44:224-44. doi: 10.1007/7854_2019_91

100. Muller N, Riedel M, Scheppach C, Brandstatter B, Sokullu S, Krampe K, et al. Beneficial antipsychotic effects of celecoxib add-on therapy compared to risperidone alone in schizophrenia. Am J Psychiatry (2002) 159(6):1029-34. doi: 10.1176/appi.ajp.159.6.1029

101. Muller N, Krause D, Dehning S, Musil R, Schennach-Wolff R, Obermeier M, et al. Celecoxib treatment in an early stage of schizophrenia: results of a randomized, double-blind, placebo-controlled trial of celecoxib augmentation of amisulpride treatment. Schizophr Res (2010) 121(13):118-24. doi: 10.1016/j.schres.2010.04.015

102. Rapaport MH, Delrahim KK, Bresee CJ, Maddux RE, Ahmadpour O, Dolnak D. Celecoxib augmentation of continuously ill patients with schizophrenia. Biol Psychiatry (2005) 57(12):1594-6. doi: 10.1016/ j.biopsych.2005.02.024

103. Sommer IE, de Witte L, Begemann M, Kahn RS. Nonsteroidal antiinflammatory drugs in schizophrenia: ready for practice or a good start? A meta-analysis. J Clin Psychiatry (2012) 73(4):414-9. doi: 10.4088/ JCP.10r06823

104. Nitta M, Kishimoto T, Muller N, Weiser M, Davidson M, Kane JM, et al. Adjunctive use of nonsteroidal anti-inflammatory drugs for schizophrenia: a meta-analytic investigation of randomized controlled trials. Schizophr Bull (2013) 39(6):1230-41. doi: 10.1093/schbul/sbt070

105. Zheng W, Cai DB, Yang XH, Ungvari GS, Ng CH, Muller N, et al. Adjunctive celecoxib for schizophrenia: A meta-analysis of randomized, double-blind, placebo-controlled trials. J Psychiatr Res (2017) 92:139-46. doi: 10.1016/ j.jpsychires.2017.04.004

106. Domercq M, Matute C. Neuroprotection by tetracyclines. Trends Pharmacol Sci (2004) 25(12):609-12. doi: 10.1016/j.tips.2004.10.001

107. Xiang YQ, Zheng W, Wang SB, Yang XH, Cai DB, Ng CH, et al. Adjunctive minocycline for schizophrenia: a meta-analysis of randomized controlled trials. Eur Neuropsychopharmacol (2017) 27(1):8-18. doi: 10.1016/ j.euroneuro.2016.11.012

108. Deakin B, Suckling J, Barnes TRE, Byrne K, Chaudhry IB, Dazzan P, et al. The benefit of minocycline on negative symptoms of schizophrenia in patients with recent-onset psychosis (BeneMin): a randomised, doubleblind, placebo-controlled trial. Lancet Psychiatry (2018) 5(11):885-94. doi: 10.1016/S2215-0366(18)30345-6

109. Raison CL, Rutherford RE, Woolwine BJ, Shuo C, Schettler P, Drake DF, et al. A randomized controlled trial of the tumor necrosis factor antagonist infliximab for treatment-resistant depression: the role of baseline inflammatory biomarkers. JAMA Psychiatry (2013) 70(1):31-41. doi: 10.1001/2013.jamapsychiatry.4

110. Miller AH, Raison CL. Are anti-inflammatory therapies viable treatments for psychiatric disorders?: where the rubber meets the road. JAMA Psychiatry (2015) 72(6):527-8. doi: 10.1001/jamapsychiatry.2015.22

111. Rapaport MH, Nierenberg AA, Schettler PJ, Kinkead B, Cardoos A, Walker R, et al. Inflammation as a predictive biomarker for response to omega-3 fatty acids in major depressive disorder: a proof-of-concept study. Mol Psychiatry (2016) 21(1):71-9. doi: 10.1038/mp.2015.22

112. Felger JC, Treadway MT. Inflammation effects on motivation and motor activity: role of dopamine. Neuropsychopharmacology (2017) 42(1):216-41. doi: $10.1038 / \mathrm{npp} .2016 .143$
113. Capuron L, Pagnoni G, Drake DF, Woolwine BJ, Spivey JR, Crowe RJ, et al. Dopaminergic mechanisms of reduced basal ganglia responses to hedonic reward during interferon alfa administration. Arch Gen Psychiatry (2012) 69 (10):1044-53. doi: 10.1001/archgenpsychiatry.2011.2094

114. Brydon L, Harrison NA, Walker C, Steptoe A, Critchley HD. Peripheral inflammation is associated with altered substantia nigra activity and psychomotor slowing in humans. Biol Psychiatry (2008) 63(11):1022-9. doi: 10.1016/j.biopsych.2007.12.007

115. Eisenberger NI, Berkman ET, Inagaki TK, Rameson LT, Mashal NM, Irwin MR. Inflammation-induced anhedonia: endotoxin reduces ventral striatum responses to reward. Biol Psychiatry (2010) 68(8):748-54. doi: 10.1016/ j.biopsych.2010.06.010

116. Harrison NA, Voon V, Cercignani M, Cooper EA, Pessiglione M, Critchley HD. A neurocomputational account of how inflammation enhances sensitivity to punishments versus rewards. Biol Psychiatry (2016) 80(1):7381. doi: 10.1016/j.biopsych.2015.07.018

117. Salamone JD, Cousins MS, Bucher S. Anhedonia or anergia? Effects of haloperidol and nucleus accumbens dopamine depletion on instrumental response selection in a T-maze cost/benefit procedure. Behav Brain Res (1994) 65(2):221-9. doi: 10.1016/0166-4328(94)90108-2

118. Felger JC, Alagbe O, Hu F, Mook D, Freeman AA, Sanchez MM, et al. Effects of interferon-alpha on rhesus monkeys: a nonhuman primate model of cytokine-induced depression. Biol Psychiatry (2007) 62(11):1324-33. doi: 10.1016/j.biopsych.2007.05.026

119. Vichaya EG, Hunt SC, Dantzer R. Lipopolysaccharide reduces incentive motivation while boosting preference for high reward in mice. Neuropsychopharmacology (2014) 39(12):2884-90. doi: 10.1038/ npp.2014.141

120. Treadway MT. The neurobiology of motivational deficits in depression-an update on candidate pathomechanisms. Curr Top Behav Neurosci (2016) 27:337-55. doi: 10.1007/7854_2015_400

121. Felger JC, Li Z, Haroon E, Woolwine BJ, Jung MY, Hu X, et al. Inflammation is associated with decreased functional connectivity within corticostriatal reward circuitry in depression. Mol Psychiatry (2016) 21(10):1358-65. doi: 10.1038/mp.2015.168

122. Park IH, Lee BC, Kim JJ, Kim JI, Koo MS. Effort-based reinforcement processing and functional connectivity underlying amotivation in medicated patients with depression and schizophrenia. J Neurosci (2017) 37(16):4370 80. doi: 10.1523/JNEUROSCI.2524-16.2017

123. Dubol M, Trichard C, Leroy C, Sandu AL, Rahim M, Granger B, et al. Dopamine transporter and reward anticipation in a dimensional perspective: a multimodal brain imaging study. Neuropsychopharmacology (2018) 43 (4):820-7. doi: 10.1038/npp.2017.183

124. Addington J, Shah H, Liu L, Addington D. Reliability and validity of the Calgary Depression Scale for Schizophrenia (CDSS) in youth at clinical high risk for psychosis. Schizophr Res (2014) 153(1-3):64-7. doi: 10.1016/ j.schres.2013.12.014

125. An der Heiden W, Leber A, Hafner H. Negative symptoms and their association with depressive symptoms in the long-term course of schizophrenia. Eur Arch Psychiatry Clin Neurosci (2016) 266(5):387-96. doi: 10.1007/s00406-016-0697-2

126. Campellone TR, Sanchez AH, Kring AM. Defeatist performance beliefs, negative symptoms, and functional outcome in schizophrenia: A Metaanalytic Review. Schizophr Bull (2016) 42(6):1343-52. doi: 10.1093/schbul/ sbw026

127. Goehler LE, Gaykema RP, Hansen MK, Anderson K, Maier SF, Watkins LR. Vagal immune-to-brain communication: a visceral chemosensory pathway. Auton Neurosci (2000) 85(1-3):49-59. doi: 10.1016/S1566-0702(00)00219-8

128. Quan N, Banks WA. Brain-immune communication pathways. Brain Behav Immun (2007) 21(6):727-35. doi: 10.1016/j.bbi.2007.05.005

129. D'Mello C, Le T, Swain MG. Cerebral microglia recruit monocytes into the brain in response to tumor necrosis factoralpha signaling during peripheral organ inflammation. J Neurosci (2009) 29(7):2089-102. doi: 10.1523/ JNEUROSCI.3567-08.2009

130. Gallego JA, Blanco EA, Husain-Krautter S, Madeline Fagen E, MorenoMerino P, Del Ojo-Jimenez JA, et al. Cytokines in cerebrospinal fluid of patients with schizophrenia spectrum disorders: New data and an updated 
meta-analysis. Schizophr Res (2018) 202:64-71. doi: 10.1016/ j.schres.2018.07.019

131. Wang AK, Miller BJ. Meta-analysis of cerebrospinal fluid cytokine and tryptophan catabolite alterations in psychiatric patients: comparisons between schizophrenia, bipolar disorder, and depression. Schizophr Bull (2018) 44(1):75-83. doi: 10.1093/schbul/sbx035

132. Felger JC, Haroon E, Patel TA, Goldsmith DR, Wommack EC, Woolwine BJ, et al. What does plasma CRP tell us about peripheral and central inflammation in depression? Mol Psychiatry (2018). doi: 10.1038/s41380018-0096-3

133. Haroon E, Miller AH. Inflammation effects on brain glutamate in depression: mechanistic considerations and treatment implications. Curr Top Behav Neurosci (2017) 31:173-98. doi: 10.1007/7854_2016_40

134. Miller AH, Haroon E, Felger JC. Therapeutic implications of brain-immune interactions: treatment in translation. Neuropsychopharmacology (2017) 42 (1):334-59. doi: 10.1038/npp.2016.167

135. Felger JC, Miller AH. Cytokine effects on the basal ganglia and dopamine function: the subcortical source of inflammatory malaise. Front Neuroendocrinol (2012) 33(3):315-27. doi: 10.1016/j.yfrne. 2012.09.003

136. Neurauter G, Schrocksnadel K, Scholl-Burgi S, Sperner-Unterweger B, Schubert C, Ledochowski M, et al. Chronic immune stimulation correlates with reduced phenylalanine turnover. Curr Drug Metab (2008) 9(7):622-7. doi: $10.2174 / 138920008785821738$

137. Haroon E, Miller AH, Sanacora G. Inflammation, glutamate, and glia: a trio of trouble in mood disorders. Neuropsychopharmacology (2017) 42(1):193215. doi: $10.1038 / \mathrm{npp} .2016 .199$

138. Gonzalez-Burgos G, Lewis DA. NMDA receptor hypofunction, parvalbumin-positive neurons, and cortical gamma oscillations in schizophrenia. Schizophr Bull (2012) 38(5):950-7. doi: 10.1093/schbul/ sbs010

139. Moghaddam B, Javitt D. From revolution to evolution: the glutamate hypothesis of schizophrenia and its implication for treatment. Neuropsychopharmacology (2012) 37(1):4-15. doi: 10.1038/ npp.2011.181

140. Howes O, McCutcheon R, Stone J. Glutamate and dopamine in schizophrenia: an update for the 21st century. J Psychopharmacol (2015) 29(2):97-115. doi: 10.1177/0269881114563634

141. Schultz W. Predictive reward signal of dopamine neurons. J Neurophysiol (1998) 80(1):1-27. doi: 10.1152/jn.1998.80.1.1

142. Waltz JA, Frank MJ, Robinson BM, Gold JM. Selective reinforcement learning deficits in schizophrenia support predictions from computational models of striatal-cortical dysfunction. Biol Psychiatry (2007) 62(7):756-64. doi: 10.1016/j.biopsych.2006.09.042

143. Shin JH, Adrover MF, Wess J, Alvarez VA. Muscarinic regulation of dopamine and glutamate transmission in the nucleus accumbens. Proc Natl Acad Sci U S A (2015) 112(26):8124-9. doi: 10.1073/pnas.1508846112

144. White DM, Kraguljac NV, Reid MA, Lahti AC. Contribution of substantia nigra glutamate to prediction error signals in schizophrenia: a combined magnetic resonance spectroscopy/functional imaging study. NPJ Schizophr (2015) 1:14001. doi: 10.1038/npjschz.2014.1

145. Salamone JD, Pardo M, Yohn SE, Lopez-Cruz L, SanMiguel N, Correa M. Mesolimbic Dopamine and the regulation of motivated behavior. Curr Top Behav Neurosci (2016) 27:231-57. doi: 10.1007/7854_2015_383

146. Stephan KE, Friston KJ, Frith CD. Dysconnection in schizophrenia: from abnormal synaptic plasticity to failures of self-monitoring. Schizophr Bull (2009) 35(3):509-27. doi: 10.1093/schbul/sbn176

147. McNabb CB, Tait RJ, Mcllwain ME, Anderson VM, Suckling J, Kydd RR, et al. Functional network dysconnectivity as a biomarker of treatment resistance in schizophrenia. Schizophr Res (2018) 195:160-7. doi: 10.1016/ j.schres.2017.10.015

148. Lynall ME, Bassett DS, Kerwin R, McKenna PJ, Kitzbichler M, Muller U, et al. Functional connectivity and brain networks in schizophrenia. $J$ Neurosci (2010) 30(28):9477-87. doi: 10.1523/JNEUROSCI.033310.2010

149. Menon V. Large-scale brain networks and psychopathology: a unifying triple network model. Trends Cognit Sci (2011) 15(10):483-506. doi: 10.1016/ j.tics.2011.08.003
150. Demjaha A, Murray RM, McGuire PK, Kapur S, Howes OD. Dopamine synthesis capacity in patients with treatment-resistant schizophrenia. Am J Psychiatry (2012) 169(11):1203-10. doi: 10.1176/appi.ajp.2012.12010144

151. Kim E, Howes OD, Veronese M, Beck K, Seo S, Park JW, et al. Presynaptic dopamine capacity in patients with treatment-resistant schizophrenia taking clozapine: an [(18)F]DOPA PET Study. Neuropsychopharmacology (2017) 42 (4):941-50. doi: 10.1038/npp.2016.258

152. Kinon BJ, Kane JM, Chakos M, Munne R. Possible predictors of neurolepticresistant schizophrenic relapse: influence of negative symptoms and acute extrapyramidal side effects. Psychopharmacol Bull (1993) 29(3):365-9.

153. Eisenberg DP, Yankowitz L, Ianni AM, Rubinstein DY, Kohn PD, Hegarty CE, et al. Presynaptic dopamine synthesis capacity in schizophrenia and striatal blood flow change during antipsychotic treatment and medicationfree conditions. Neuropsychopharmacology (2017) 42(11):2232-41. doi: 10.1038/npp.2017.67

154. Howes OD, Kapur S. The dopamine hypothesis of schizophrenia: version III-the final common pathway. Schizophr Bull (2009) 35(3):549-62. doi: $10.1093 / \mathrm{schbul} / \mathrm{sbp} 006$

155. Mouchlianitis E, Bloomfield MA, Law V, Beck K, Selvaraj S, Rasquinha N, et al. Treatment-resistant schizophrenia patients show elevated anterior cingulate cortex glutamate compared to treatment-responsive. Schizophr Bull (2016) 42(3):744-52. doi: 10.1093/schbul/sbv151

156. Foussias G, Siddiqui I, Fervaha G, Agid O, Remington G. Dissecting negative symptoms in schizophrenia: opportunities for translation into new treatments. J Psychopharmacol (2015) 29(2):116-26. doi: 10.1177/ 0269881114562092

157. Galderisi S, Mucci A, Buchanan RW, Arango C. Negative symptoms of schizophrenia: new developments and unanswered research questions. Lancet Psychiatry (2018) 5(8):664-77. doi: 10.1016/S2215-0366(18)30050-6

158. Shim S, Shuman M, Duncan E. An emerging role of cGMP in the treatment of schizophrenia: a review. Schizophr Res (2016) 170(1):226-31. doi: 10.1016/ j.schres.2015.11.015

159. Revel FG, Moreau JL, Pouzet B, Mory R, Bradaia A, Buchy D, et al. A new perspective for schizophrenia: TAAR1 agonists reveal antipsychotic- and antidepressant-like activity, improve cognition and control body weight. Mol Psychiatry (2013) 18(5):543-56. doi: 10.1038/mp.2012.57

160. McGuire P, Robson P, Cubala WJ, Vasile D, Morrison PD, Barron R, et al. Cannabidiol (CBD) as an adjunctive therapy in schizophrenia: a multicenter randomized controlled trial. Am J Psychiatry (2018) 175(3):225-31. doi: 10.1176/appi.ajp.2017.17030325

161. Krogmann A, Peters L, von Hardenberg L, Bodeker K, Nohles VB, Correll $\mathrm{CU}$. Keeping up with the therapeutic advances in schizophrenia: a review of novel and emerging pharmacological entities. CNS Spectr (2019) 24(S1):3869. doi: $10.1017 /$ S109285291900124X

162. Miller BJ, Goldsmith DR. Towards an immunophenotype of schizophrenia: progress, potential mechanisms, and future directions. Neuropsychopharmacology (2017) 42(1):299-317. doi: 10.1038/npp.2016.211

163. Kirkpatrick B, Strauss GP, Nguyen L, Fischer BA, Daniel DG, Cienfuegos A, et al. The brief negative symptom scale: psychometric properties. Schizophr Bull (2011) 37(2):300-5. doi: 10.1093/schbul/sbq059

164. Kring AM, Gur RE, Blanchard JJ, Horan WP, Reise SP. The Clinical Assessment Interview for Negative Symptoms (CAINS): final development and validation. Am J Psychiatry (2013) 170(2):165-72. doi: 10.1176/ appi.ajp.2012.12010109

165. Llerena K, Park SG, McCarthy JM, Couture SM, Bennett ME, Blanchard JJ. The motivation and pleasure scale-self-report (MAP-SR): reliability and validity of a self-report measure of negative symptoms. Compr Psychiatry (2013) 54(5):568-74. doi: 10.1016/j.comppsych.2012.12.001

166. Treadway MT, Buckholtz JW, Schwartzman AN, Lambert WE, Zald DH. Worth the "EEfRT"? The effort expenditure for rewards task as an objective measure of motivation and anhedonia. PloS One (2009) 4(8):e6598. doi: 10.1371/journal.pone.0006598

167. Lasselin J, Treadway MT, Lacourt TE, Soop A, Olsson MJ, Karshikoff B, et al. Lipopolysaccharide alters motivated behavior in a monetary reward task: a randomized trial. Neuropsychopharmacology (2017) 42(4):801-10. doi: 10.1038/npp.2016.191

168. Cooper JA, Barch DM, Reddy LF, Horan WP, Green MF, Treadway MT. Effortful goal-directed behavior in schizophrenia: Computational subtypes 
and associations with cognition. J Abnorm Psychol (2019) 128(7):710-22. doi: $10.1037 / \mathrm{abn} 0000443$

169. Miller AH, Raison CL. The role of inflammation in depression: from evolutionary imperative to modern treatment target. Nat Rev Immunol (2016) 16(1):22-34. doi: 10.1038/nri.2015.5

170. Pearson TA, Mensah GA, Alexander RW, Anderson JL, Cannon RO3rd, Criqui $\mathrm{M}$, et al. Markers of inflammation and cardiovascular disease: application to clinical and public health practice: a statement for healthcare professionals from the Centers for Disease Control and Prevention and the American Heart Association. Circulation (2003) 107 (3):499-511. doi: 10.1161/01.CIR.0000052939.59093.45

171. Girgis RR, Ciarleglio A, Choo T, Haynes G, Bathon JM, Cremers S, et al. A randomized, double-blind, placebo-controlled clinical trial of tocilizumab, an interleukin-6 receptor antibody, for residual symptoms in schizophrenia. Neuropsychopharmacology (2018) 43(6):1317-23. doi: 10.1038/npp.2017.258

172. Jha MK, Minhajuddin A, Gadad BS, Greer T, Grannemann B, Soyombo A, et al. Can C-reactive protein inform antidepressant medication selection in depressed outpatients? Findings from the CO-MED trial. Psychoneuroendocrinology (2017) 78:105-13. doi: 10.1016/ j.psyneuen.2017.01.023

173. Miller BJ, Buckley P, Seabolt W, Mellor A, Kirkpatrick B. Meta-analysis of cytokine alterations in schizophrenia: clinical status and antipsychotic effects. Biol Psychiatry (2011) 70(7):663-71. doi: 10.1016/j.biopsych.2011.04.013

174. Upthegrove R, Manzanares-Teson N, Barnes NM. Cytokine function in medication-naive first episode psychosis: a systematic review and metaanalysis. Schizophr Res (2014) 155(1-3):101-8. doi: 10.1016/ j.schres.2014.03.005

175. Park S, Miller BJ. Meta-analysis of cytokine and C-reactive protein levels in high-risk psychosis. Schizophr Res (2019). doi: 10.1016/j.schres.2019.03.012

176. Murakami M, Kamimura D, Hirano T. Pleiotropy and specificity: insights from the interleukin 6 family of cytokines. Immunity (2019) 50(4):812-31. doi: 10.1016/j.immuni.2019.03.027

177. Hodes GE, Pfau ML, Leboeuf M, Golden SA, Christoffel DJ, Bregman D, et al. Individual differences in the peripheral immune system promote resilience versus susceptibility to social stress. Proc Natl Acad Sci U S A (2014) 111 (45):16136-41. doi: 10.1073/pnas.1415191111

178. Tanaka T, Narazaki M, Masuda K, Kishimoto T. Regulation of IL-6 in Immunity and Diseases. Adv Exp Med Biol (2016) 941:79-88. doi: 10.1007/ 978-94-024-0921-5_4
179. Kowalchuk C, Kanagasundaram P, Belsham DD, Hahn MK. Antipsychotics differentially regulate insulin, energy sensing, and inflammation pathways in hypothalamic rat neurons. Psychoneuroendocrinology (2019) 104:42-8. doi: 10.1016/j.psyneuen.2019.01.029

180. Pillinger T, Beck K, Gobjila C, Donocik JG, Jauhar S, Howes OD. Impaired glucose homeostasis in first-episode schizophrenia: a systematic review and meta-analysis. JAMA Psychiatry (2017) 74(3):261-9. doi: 10.1001/ jamapsychiatry.2016.3803

181. Harrison NA, Brydon L, Walker C, Gray MA, Steptoe A, Dolan RJ, et al. Neural origins of human sickness in interoceptive responses to inflammation. Biol Psychiatry (2009) 66(5):415-22. doi: 10.1016/ j.biopsych.2009.03.007

182. Haroon E, Chen X, Li Z, Patel T, Woolwine BJ, Hu XP, et al. Increased inflammation and brain glutamate define a subtype of depression with decreased regional homogeneity, impaired network integrity, and anhedonia. Transl Psychiatry (2018) 8(1):189. doi: 10.1038/s41398-0180241-4

183. O'Neill LA, Kishton RJ, Rathmell J. A guide to immunometabolism for immunologists. Nat Rev Immunol (2016) 16(9):553-65. doi: 10.1038/ nri.2016.70

184. Treadway MT, Cooper JA, Miller AH. Can't or won't? immunometabolic constraints on dopaminergic drive. Trends Cognit Sci (2019) 23(5):435-48. doi: 10.1016/j.tics.2019.03.003

185. Plitman E, Iwata Y, Caravaggio F, Nakajima S, Chung JK, Gerretsen P, et al. Kynurenic acid in schizophrenia: a systematic review and metaanalysis. Schizophr Bull (2017) 43(4):764-77. doi: 10.1093/schbul/ sbw221

186. Savitz J. The kynurenine pathway: a finger in every pie. Mol Psychiatry (2019) 1:131-47 doi: 10.1038/s41380-019-0414-4

Conflict of Interest: The authors declare that the research was conducted in the absence of any commercial or financial relationships that could be construed as a potential conflict of interest.

Copyright $(2020$ Goldsmith and Rapaport. This is an open-access article distributed under the terms of the Creative Commons Attribution License (CC BY). The use, distribution or reproduction in other forums is permitted, provided the original author (s) and the copyright owner(s) are credited and that the original publication in this journal is cited, in accordance with accepted academic practice. No use, distribution or reproduction is permitted which does not comply with these terms. 